\title{
Direct and indirect costs of cluster headache: a prospective analysis in a tertiary level headache centre
}

Andrea Negro ${ }^{1,2^{*}+}$ (D), Paolo Sciattella ${ }^{3,4 \dagger}$, Valerio Spuntarelli ${ }^{1}$, Paolo Martelletti ${ }^{1,2}$ and Francesco Saverio Mennini ${ }^{3,5}$

\begin{abstract}
Background: Cluster headache $(\mathrm{CH})$ is the most frequent trigemino-autonomic cephalgia. $\mathrm{CH}$ can manifest as episodic $(\mathrm{ECH})$ or chronic cluster headache $(\mathrm{CCH})$ causing significant burden of disease and requiring attack therapy and prophylactic treatment. The few data available on the economic burden of $\mathrm{CH}$ come from retrospective studies based on questionnaires, population surveys and medical insurance claims database. Although all these studies showed an important economic burden, they provided different estimates depending on variability of $\mathrm{CH}$ awareness and management, healthcare systems, available therapies and use of treatments according to different guidelines.
\end{abstract}

Methods: This prospective study aimed to quantify the total direct and indirect cost of ECH and CCH over a cluster period, both for the patient and for the National Health System (NHS), using data from subjects who consecutively attended an Italian tertiary headache centre between January 1, 2018 and December 31, 2018.

Results: A total 108 patients ( $89 \mathrm{ECH}, 19 \mathrm{CCH}$ ) were included. Mean attack frequency was $2.3 \pm 1.4$ per day. Mean total cost of a $\mathrm{CH}$ bout was $€ 4398$ per patient and total cost of $\mathrm{CCH}$ was 5.4 times higher than $\mathrm{ECH}(€ 13,350 \mathrm{vs}$. $€ 2487, p<0.001)$. Direct costs represented the $72.1 \%$ of total cost and were covered for the $94.8 \%$ by the NHS. The costs for any item of expense were higher for $\mathrm{CCH}$ than for $\mathrm{ECH}(p<0.001)$. Mean indirect costs for a $\mathrm{CH}$ bout were $€ 1226$ per patient and were higher for CCH compared to ECH ( $€ 3.538$ vs. $€ 732$ ), but the difference was not significant. Days with reduced productive capacity impacted for the $64.6 \%$ of the total indirect costs. The analysis of the impact $\mathrm{CH}$ on work showed that $27 \% \%$ of patients felt that $\mathrm{CH}$ had limited their career, $40 \%$ had changed their work pattern, 20\% had changed their place of employment and 10\% had lost a job due to the disease.

Conclusion: Our results provide a valuable estimate of the direct and indirect costs of ECH and CCH in the specific setting of a tertiary headache centre and confirm the high economic impact of $\mathrm{CH}$ on both the NHS and patients.

Keywords: Cost of illness, Cluster headache, Chronic cluster headache, Episodic cluster headache, Burden of disease, Resource utilization

\footnotetext{
* Correspondence: andrea.negro@uniroma1.it

${ }^{\dagger}$ Andrea Negro and Paolo Sciattella contributed equally to this work.

'Department of Clinical and Molecular Medicine, Sapienza University, Rome,

Italy

${ }^{2}$ Regional Referral Headache Centre, Sant'Andrea Hospital, Rome, Italy

Full list of author information is available at the end of the article
}

C C The Author(s). 2020 Open Access This article is licensed under a Creative Commons Attribution 4.0 International License, which permits use, sharing, adaptation, distribution and reproduction in any medium or format, as long as you give appropriate credit to the original author(s) and the source, provide a link to the Creative Commons licence, and indicate if changes were made. The images or other third party material in this article are included in the article's Creative Commons licence, unless indicated otherwise in a credit line to the material. If material is not included in the article's Creative Commons licence and your intended use is not permitted by statutory regulation or exceeds the permitted use, you will need to obtain permission directly from the copyright holder. To view a copy of this licence, visit http://creativecommons.org/licenses/by/4.0/ The Creative Commons Public Domain Dedication waiver (http://creativecommons.org/publicdomain/zero/1.0/) applies to the data made available in this article, unless otherwise stated in a credit line to the data. 


\section{Introduction}

Cluster headache $(\mathrm{CH})$ is the most frequent of the socalled trigemino-autonomic cephalgias (TACs) and is the most severe of primary headaches. $\mathrm{CH}$ is characterized by excruciating unilateral pain lasting from $15 \mathrm{~min}$ to $3 \mathrm{~h}$, with attacks occurring every other day up to eight times a day for weeks or months during active cluster periods, followed by periods of remission. Attacks are accompanied by a sense of restlessness or agitation and ipsilateral cranial autonomic features common to all TACs, such as conjunctival injection and/or lacrimation, nasal congestion and/or rhinorrhea, eyelid oedema, forehead and facial sweating, and miosis and/or ptosis [1]. The age of onset is typically between 20 and 40 years with a 3-fold male preponderance. $\mathrm{CH}$ is relatively rare compared with other primary headaches, as demonstrated by a meta-analysis of 15 studies in 10 countries that estimated a worldwide lifetime-prevalence of around 1 per 1000 in all age groups [2]. There are 2 types of $\mathrm{CH}$ : episodic $\mathrm{CH}(\mathrm{ECH})$ and chronic $\mathrm{CH}(\mathrm{CCH})$. According to the third edition of the International Classification of Headache Disorders (ICHD3) [1], patients with ECH suffer from headache attacks that occur in periods ranging from 7 days to 1 year, separated by pain-free periods lasting at least 3 months. $\mathrm{CH}$ occurs in $85-90 \%$ of patients as episodic with an average bouts duration of 8.6 weeks [3]. The remaining 10 $15 \%$ of patients suffer from $\mathrm{CCH}$ ), without such periods of remission.

Almost a third of the patients with ECH at onset develops $\mathrm{CCH} 10$ years later and the same proportion of patients with $\mathrm{CCH}$ at onset turns into episodic within 10 years [4]. Unfortunately, half of patients with $\mathrm{CCH}$ at onset still have $\mathrm{CCH}$ after 20 years or more [4] and a considerable proportion often resist pharmaceutical treatments leading to refractory $\mathrm{CCH}$ as defined by the European Headache Federation (EHF) [5].

The pathogenesis of $\mathrm{CH}$ is incompletely understood, although evidence suggests that the trigeminovascular system and neurogenic inflammation play important roles and hypothalamic activation is suspected to be a key factor in the generation of attacks [6]. Treatment of $\mathrm{CH}$ is based exclusively on pharmacological measures and consists of two basic principles: symptomatic therapy taken at the time of an attack and preventive treatment to suppress further attacks. When a new cluster bout begins, both acute symptomatic and preventive therapy should be initiated. In addition to preventive medication, transitional therapies (e.g., oral steroids and suboccipital steroid injections) are often used to achieve short-term symptom improvement until the preventive drug dose can be increased and becomes effective. This therapeutic approach is particularly suitable for those patients with a high frequency of attacks.
$\mathrm{CH}$ has often been referred to as "suicide headache" due to the excruciating pain of the attacks and although these are periodic in most cases, the personal burden can be considerable due to lifestyle restrictions during the bouts, increased use of health care and the negative impact on work [7]. The few data available on the economic burden of $\mathrm{CH}$ come from retrospective studies based on questionnaires, population surveys and medical insurance claims database [8-10]. Although all these studies showed an important economic burden, they provided different estimates depending on variability of $\mathrm{CH}$ awareness and management, healthcare systems, available therapies and use of treatments according to different guidelines.

Therefore, this study was conducted in a tertiary headache centre to estimate the total cost (direct and indirect) of treating $\mathrm{ECH}$ and $\mathrm{CCH}$ over a cluster period and to determine the economic burden for patients and the National Health System (NHS).

\section{Methods \\ Study design}

The study is a prospective and cross-sectional evaluation of the direct and indirect costs of $\mathrm{ECH}$ and $\mathrm{CCH}$, carried out at the outpatient Regional Referral Headache Centre, Department of Clinical and Molecular Medicine, Faculty of Medicine and Psychology, Sapienza University of Rome.

The study population included all patients with $\mathrm{CH}$ who consecutively attended our tertiary level headache center between January 1, 2018 and December 31, 2018. The headache diaries designed specifically for $\mathrm{CH}$ were given to participants to record the amount and duration of use (e.g., oxygen inhalation) of the prescribed acute, preventive and oral transitional treatments. Headache diaries were also used to record days off work and days with reduced work efficiency. Patients' electronic medical records (EMRs) were used to collect further information, such as the number of visits to our headache centre, other specialist visits, diagnostic tests, therapeutic procedures performed at our clinic (e.g. steroid suboccipital injections) and admissions to the emergency department (ED). Patients' EMRs are updated at each visit with information obtained from the patient and with data extracted from the headache diary.

Inclusion criteria were: 1) diagnosis of $\mathrm{CH}$ (according to ICHD3 [1]); 2) age $\geq 18$ years at the time of enrollment; 3 ) continuous treatment for the entire duration of the cluster bout; and 4) complete compilation of the headache diary reporting medication consumptions.

\section{Data analysis}

The data collected included demographic characteristics, medical history of $\mathrm{CH}$, number of specialist visits, number of diagnostic tests (e.g. electrocardiogram and brain 
magnetic resonance), medication consumption (acute, transitional and preventive drugs) and number of ED admissions. In Italy, ED visits are fully funded by the NHS, while specialist visits, diagnostic tests, hospital therapeutic procedures and medications may be partially funded by the NHS or fully paid by the patient. The use of drugs has been quantified by analyzing patients' headache diary records. Similarly, indirect costs due to days of absence from work and days with reduced work efficiency were assessed analyzing the data recorded by participants in their diaries.

\section{Economic analysis}

The costs have been estimated from both societal and patient perspective. Intangible costs were not included in this evaluation. The costs have been calculated for the entire duration of a $\mathrm{CH}$ period. All costs are expressed in Euros and adjusted for the year 2019. Estimates of direct costs are the total of everything that has been paid or reimbursed by the NHS plus payments of own pocket money. Unit costs have been collected from publicly available sources in the calendar year 2019. The Regional Tariff Nomenclator for Outpatient Specialist Services was considered for outpatient specialist services [11] while each ED visit was considered to be $€ 241$ [12]. The costs of the drugs have been estimated using the reimbursement price of the Regional Health System for the classes of drugs charged to the NHS [13], while the costs of classes of drugs partially charged to the NHS or totally charged to the patient have been identified by a private site for health care professionals.

In addition, indirect costs caused by disability have been calculated according to the "cost of illness" methodology among gainfully employed subjects, both fulltime and part-time [14]. The daily cost was calculated from the societal perspective using average labor costs. The cost of illness has been calculated by multiplying resource consumption and estimated prices.

\section{Statistics}

The demographic and clinical characteristics, the number of specialist visits, the number of diagnostic tests, the consumption of drugs (reimbursed and not reimbursed by the NHS) and the number of ED visits have been assessed in a descriptive way. The categorical data were summarized by numbers and percentages, the continuous data by mean \pm standard deviation (SD). The descriptive statistics are presented as means \pm SD. The presence of statistically significant differences between $\mathrm{ECH}$ and $\mathrm{CCH}$ patients was evaluated by Chi-square test and Fisher exact test, when appropriate, for proportion, Student's $\mathrm{T}$ tests for normal distributions and MannWhitney tests for non-normal distributions. All analyses were performed using the SAS statistical package, version 9.4 (SAS Institute Inc., Cary, NC, USA).

\section{Results \\ Patients characteristics}

The sample analyzed consisted of 108 patients, 9 (8.3\%) women and 99 (91.7\%) men, aged between 22 and 76 years. Patient characteristics are shown in Table 1. The average age of men was $44.1 \pm 11.8$ years and of women was $36.2 \pm 12.3$ years. The age at onset of $\mathrm{CH}$ was $30 \pm$ 11 years. According to the ICHD-III diagnostic criteria, 89 (82.4\%) subjects had ECH and 19 (17.6\%) had $\mathrm{CCH}$. On average, patients had $2.3 \pm 1.4$ attacks per day $(\mathrm{CCH}$ : $2.2 \pm 1.7, \mathrm{ECH}: 2.4 \pm 1.3$ ) with a range from 0.4 (3 per week) to 6 attacks per day. The mean duration of bouts in the total population was $14.8 \pm 17.9$ weeks with a minimum of 1 week to a maximum of 12 months. The mean duration of bouts among ECH patients was $6.8 \pm$ 5.1 weeks with a minimum of 1 week to a maximum of 6 months.

\section{Specialist visits}

Patients enrolled in the study consulted our outpatient headache centre with an average number of $3.0 \pm 1.9$ visits (range 1-9) during the $\mathrm{CH}$ period (Table 2). The average number of headache visits was higher for $\mathrm{CCH}(6.7 \pm 1.5$; range: $4-9)$ than ECH $(2.2 \pm 0.7$, range $1-5 ; p<0.0001)$. A cardiologist was consulted by $13(68.4 \%) \mathrm{CCH}$ patients and by $23(11.2 \%) \mathrm{ECH}$ patients $(p<0.0001)$.

The mean cost of specialist visits was $€ 169 \pm € 114$ (range: €53-527) per patient, covered by NHS for the $39 \%$, and was significantly higher for CCH $(€ 391 \pm € 77)$ than ECH $(€ 122 \pm € 42 ; \mathrm{p}<0.0001)$ (Table 3).

\section{Diagnostic tests}

The use of at least one diagnostic during the bout involved 71 (65.7\%) patients (Table 2). Seventy-one (65.7\%) patients received at least one electrocardiogram (ECG). Higher proportion of $\mathrm{CCH}$ patients had prescribed an ECG compared to ECH patients (94.7.\% vs. 59.6\%; p 0.002). The mean number of ECG per patient was higher for $\mathrm{CCH}(2.5 \pm 1.2)$ than $\mathrm{ECH}(0.6 \pm 0.7$; $p<0.0001)$. Thirty-seven (34.3\%) patients underwent to brain magnetic resonance imaging (MRI). Higher proportion of $\mathrm{CCH}$ patients received a prescription for a brain MRI compared to ECH patients $(84.2 \%$ vs. $23.6 \%$; $p<0.0001)$. The mean number of brain MRI per patient was higher for $\mathrm{CCH}(0.8 \pm 0.4)$ than $\mathrm{ECH}(0.2 \pm 0.4$; $p<0.0001$ ).

The diagnostic tests had an average cost per patient of $€ 204 \pm € 237$ (range: $€ 0-691$ ), covered by the NHS for $82.4 \%(€ 168 \pm € 200)$. The cost was significantly higher for $\mathrm{CCH} \quad(€ 520 \pm € 188)$ than $\mathrm{ECH} \quad(€ 137 \pm € 187$; $p<0.0001$ ) (Table 3). 
Table 1 Patients characteristics: demographic, occupational and medical

\begin{tabular}{|c|c|c|c|c|}
\hline Diagnosis & $\begin{array}{c}\mathrm{ECH} \\
(n=89)\end{array}$ & $\begin{array}{c}\mathrm{CCH} \\
(n=19)\end{array}$ & $\begin{array}{c}\text { Total } \\
(n=108) \\
\end{array}$ & $p$-value \\
\hline Men, n. (\%) & $81(91)$ & $18(95)$ & $99(92)$ & N.S. \\
\hline Women, n. (\%) & $8(9)$ & $1(5)$ & $9(8)$ & \\
\hline Age, years & $\begin{array}{c}43.4 \pm 12.5 \\
(22-76)\end{array}$ & $\begin{array}{c}43.8 \pm 9.5 \\
(23-62)\end{array}$ & $\begin{array}{c}43.4 \pm 12.0 \\
(22-76)\end{array}$ & N.S. \\
\hline \multicolumn{5}{|l|}{ Level of education, n. (\%) } \\
\hline Primary & $4(4)$ & $0(0)$ & $4(4)$ & \multirow[t]{3}{*}{ N.S. } \\
\hline Secondary & $35(39)$ & $7(37)$ & $42(39)$ & \\
\hline Degree & $50(56)$ & $12(63)$ & $62(57)$ & \\
\hline \multicolumn{5}{|l|}{ Gross annual income (€) } \\
\hline 0 & $21(24)$ & $7(37)$ & $28(26)$ & \multirow[t]{4}{*}{ N.S. } \\
\hline$<10,000$ & $19(21)$ & $5(26)$ & $24(22)$ & \\
\hline $10,000-24,999$ & $32(36)$ & $3(16)$ & $35(32)$ & \\
\hline$\geq 25,000$ & $17(19)$ & $4(21)$ & $21(19)$ & \\
\hline \multicolumn{5}{|l|}{ Employment status, n. (\%) } \\
\hline Employed (full-time) & $48(53.9)$ & $7(36.8)$ & $55(50.9)$ & \multirow[t]{5}{*}{0.016} \\
\hline Employed (part-time) & $20(22.5)$ & $5(26.3)$ & $25(23.1)$ & \\
\hline Retired & $6(6.7)$ & $0(0)$ & $6(5.6)$ & \\
\hline Unemployed & $7(7.9)$ & $7(36.8)$ & $14(13)$ & \\
\hline Housewife/student & $8(9)$ & $0(0)$ & $8(7.4)$ & \\
\hline Age at onset, years & $\begin{array}{c}30.5 \pm 11.4 \\
(14-64)\end{array}$ & $\begin{array}{c}29.9 \pm 10.2 \\
(18-56)\end{array}$ & $\begin{array}{c}30.4 \pm 11.2 \\
(14-64)\end{array}$ & N.S. \\
\hline Duration of disease, years & $\begin{array}{c}12.8 \pm 10.0 \\
(0-37)\end{array}$ & $\begin{array}{c}13.9 \pm 7.1 \\
(0-30)\end{array}$ & $\begin{array}{c}13,0 \pm 9.5 \\
(0-37)\end{array}$ & N.S. \\
\hline Diagnostic delay, years & $\begin{array}{c}4.2 \pm 3.6 \\
(0-16)\end{array}$ & $\begin{array}{c}2.7 \pm 1.8 \\
(0-7)\end{array}$ & $\begin{array}{c}3.9 \pm 3.4 \\
(0-16)\end{array}$ & N.S. \\
\hline New CH diagnosis, n. (\%) & $30(33.7)$ & $1(5.3)$ & $31(28.7)$ & 0.012 \\
\hline Frequency of attacks, per day & $\begin{array}{l}2.4 \pm 1.3 \\
(0.4-5.0)\end{array}$ & $\begin{array}{l}2.2 \pm 1.7 \\
(0.4-6.0)\end{array}$ & $\begin{array}{l}2.3 \pm 1.4 \\
(0.4-6.0)\end{array}$ & N.S. \\
\hline Duration of attack without treatment, min. & $\begin{array}{c}64.3 \pm 32.2 \\
(20-150)\end{array}$ & $\begin{array}{c}79.7 \pm 31.3 \\
(35-150)\end{array}$ & $\begin{array}{c}67.0 \pm 32.4 \\
(20-150)\end{array}$ & 0.30 \\
\hline Duration of attack with treatment, min. & $\begin{array}{c}13.7 \pm 5.6 \\
(5-40)\end{array}$ & $\begin{array}{c}13.5 \pm 4.7 \\
(8-25)\end{array}$ & $\begin{array}{c}13.6 \pm 5.4 \\
(5-40)\end{array}$ & N.S. \\
\hline Duration of bouts, weeks & $\begin{array}{c}6.8 \pm 5.1 \\
(1-25)\end{array}$ & $\begin{array}{c}52.0 \pm 0 \\
(52)\end{array}$ & $\begin{array}{c}14.8 \pm 17.9 \\
(1-52)\end{array}$ & $<0.0001$ \\
\hline Laterality, left, n. (\%) & $46(52)$ & $8(42)$ & $54(50$ & N.S. \\
\hline \multicolumn{5}{|l|}{ CH symptoms, n. (\%) } \\
\hline conjunctival injection and/or lacrimation & $45(50.6)$ & $12(63.2)$ & $57(52.8)$ & N.S. \\
\hline nasal congestion and/or rhinorrhoea & $54(60.7)$ & $8(42.1)$ & $62(57.4)$ & N.S. \\
\hline eyelid oedema & $66(74.2)$ & $15(78.9)$ & $81(75)$ & N.S. \\
\hline forehead and facial sweating & $41(46.1)$ & $8(42.1)$ & $49(45.4)$ & N.S. \\
\hline miosis and/or ptosis & $40(44.9)$ & $11(57.9)$ & $51(47.2)$ & N.S. \\
\hline sense of restlessness or agitation & $65(73)$ & $14(73.7)$ & $79(73.1)$ & N.S. \\
\hline
\end{tabular}

$\mathrm{CCH}$ Chronic cluster headache, ECH Episodic cluster headache 
Table 2 Healthcare resource use

\begin{tabular}{|c|c|c|c|c|}
\hline Diagnosis & $\begin{array}{c}\mathrm{ECH} \\
(n=89)\end{array}$ & $\begin{aligned} & \mathrm{CCH} \\
&(n=19)\end{aligned}$ & $\begin{array}{r}\text { Total } \\
(n=108)\end{array}$ & $p$-value \\
\hline Headache centre visits, $n$. & $2.2 \pm 0.7(1-5)$ & $6.7 \pm 1.5(4-9)$ & $3.0 \pm 1.9(1-9)$ & $<0.0001$ \\
\hline Cardiology visits, n. (\%) patients & $10(11.2)$ & $13(68.4)$ & $23(21.3)$ & $<0.0001$ \\
\hline ED visits, $n$. (\%) patients & $14(15.7)$ & $11(57.9)$ & $25(23.1)$ & $<0.0001$ \\
\hline ED visits, $n$. per patient & $0.2 \pm 0.6(0-3)$ & $0.7 \pm 0.7(0-2)$ & $0.3 \pm 0.6(0-3)$ & 0.000 \\
\hline ECG, $n$. (\%) patients & $53(59.6)$ & $18(94.7)$ & $71(65.7)$ & 0.002 \\
\hline ECG, n. per patient & $0.6 \pm 0.7(0-3)$ & $2.5 \pm 1.2(0-4)$ & $0.9 \pm 1.1(0-4)$ & $<0.0001$ \\
\hline Brain MRI, n. (\%) patients & 21 (23.6) & $16(84.2)$ & $37(34.3)$ & $<0.0001$ \\
\hline Brain MRI, $n$. per patient & $0.2 \pm 0.4(0-1)$ & $0.8 \pm 0.4(0-1)$ & $0.3 \pm 0.5(0-1)$ & $<0.0001$ \\
\hline \multicolumn{5}{|l|}{ Acute medications, $n$. (\%) } \\
\hline Sumatriptan $6 \mathrm{mg}$ & $56(62.9)$ & $17(89.5)$ & $73(67.6)$ & 0.030 \\
\hline Zolmitriptan $5 \mathrm{mg}$ & $19(21.3)$ & $1(5.3)$ & $20(18.5)$ & N.S. \\
\hline Oxygen & $71(79.8)$ & $19(100)$ & $90(83.3)$ & 0.038 \\
\hline Combinations & $57(64)$ & $18(94.7)$ & $75(69.4)$ & 0.007 \\
\hline \multicolumn{5}{|l|}{ Transitional treatments, $n$. (\%) } \\
\hline Oral corticosteroids & $29(32.6)$ & $0(0)$ & $29(26.9)$ & 0.002 \\
\hline G.O.N. block & $8(9)$ & $15(78.9)$ & $23(21.3)$ & $<0.0001$ \\
\hline \multicolumn{5}{|l|}{ Preventive medications, $n$. (\%) } \\
\hline Verapamil & $62(69.7)$ & $15(78.9)$ & $77(71.3)$ & N.S. \\
\hline Topiramate & $30(33.7)$ & $11(57.9)$ & $41(38)$ & 0.048 \\
\hline Combinations & $51(57.3)$ & $18(94.7)$ & $69(63.9)$ & 0.001 \\
\hline \multicolumn{5}{|l|}{ Nutraceutics, n. (\%) } \\
\hline Melatonin & $31(34.8)$ & $17(89.5)$ & $48(44.4)$ & $<0.0001$ \\
\hline
\end{tabular}

CCH Chronic cluster headache, ECH Episodic cluster headache, ECG Electrocardiogram, ED Emergency department, GON Great occipital nerve, MRI Magnetic resonance imaging

Table 3 Direct costs per $\mathrm{CH}$ bout

\begin{tabular}{|c|c|c|c|c|c|c|c|}
\hline \multirow[t]{2}{*}{ Diagnosis } & \multicolumn{2}{|c|}{$\mathrm{EEC}(n=89)$} & \multicolumn{2}{|c|}{$\mathrm{CCH}(n=19)$} & \multicolumn{2}{|c|}{ Total $(n=108)$} & \multirow[t]{2}{*}{$p$-value } \\
\hline & $\mathrm{NHS}$ & PRI & $\mathrm{NHS}$ & PRI & $\mathrm{NHS}$ & PRI & \\
\hline Specialist visits & $\begin{array}{l}€ 48 \pm € 16 \\
(21-103)\end{array}$ & $\begin{array}{l}€ 74 \pm € 25 \\
(32-160)\end{array}$ & $\begin{array}{l}€ 153 \pm € 30 \\
(103-207)\end{array}$ & $\begin{array}{l}€ 237 \pm € 47 \\
(160-320)\end{array}$ & $\begin{array}{l}€ 66 \pm € 45 \\
(21-207)\end{array}$ & $€ 103 \pm € 69(32-320)$ & $<0.0001$ \\
\hline ED visit & $\begin{array}{l}€ 51 \pm € 133 \\
(0-723)\end{array}$ & - & $\begin{array}{l}€ 165 \pm € 162 \\
(0-482)\end{array}$ & - & $\begin{array}{l}€ 71 \pm € 145 \\
(0-723)\end{array}$ & - & 0.000 \\
\hline Diagnostic tests & $\begin{array}{l}€ 113 \pm € 161 \\
(0-506)\end{array}$ & $\begin{array}{l}€ 24 \pm € 27 \\
(0-111)\end{array}$ & $\begin{array}{l}€ 426 \pm € 156 \\
(0-558)\end{array}$ & $\begin{array}{l}€ 94 \pm € 34 \\
(0-133)\end{array}$ & $\begin{array}{l}€ 168 \pm € 200 \\
(0-558)\end{array}$ & $\begin{array}{l}€ 36 \pm € 39 \\
(0-133)\end{array}$ & $<0.0001$ \\
\hline Acute medications & $\begin{array}{l}€ 1387 \pm € 1938 \\
(14-8724)\end{array}$ & - & $\begin{array}{l}€ 8314 \pm € 6822 \\
(362-25,024)\end{array}$ & - & $\begin{array}{l}€ 2606 \pm € 4236 \\
(14-25,024)\end{array}$ & - & $<0.0001$ \\
\hline Transitional treatments & $\begin{array}{l}€ 7 \pm € 15 \\
(0-60)\end{array}$ & $\begin{array}{l}€ 3 \pm € 9 \\
(0-32)\end{array}$ & $\begin{array}{l}€ 41 \pm € 22 \\
(0-52)\end{array}$ & $\begin{array}{l}€ 25 \pm € 13 \\
(0-32)\end{array}$ & $\begin{array}{l}€ 13 \pm € 21 \\
(0-60)\end{array}$ & $\begin{array}{l}€ 7 \pm € 13 \\
(0-32)\end{array}$ & $<0.0001$ \\
\hline Preventive medications & $\begin{array}{l}€ 40 \pm € 58 \\
(0-371)\end{array}$ & $\begin{array}{l}€ 8 \pm € 15 \\
(0-60)\end{array}$ & $\begin{array}{l}€ 275 \pm € 85 \\
(153-445)\end{array}$ & $\begin{array}{l}€ 82 \pm € 29 \\
(0-91)\end{array}$ & $\begin{array}{l}€ 81 \pm € 110 \\
(0-445)\end{array}$ & $\begin{array}{l}€ 21 \pm € 33 \\
(0-91)\end{array}$ & $<0.0001$ \\
\hline \multirow[t]{2}{*}{ Total } & $\begin{array}{l}€ 1647 \pm € 2064 \\
(34-9629)\end{array}$ & $\begin{array}{l}€ 109 \pm € 60 \\
(32-299)\end{array}$ & $\begin{array}{l}€ 9374 \pm € 6898 \\
(1382-26,147)\end{array}$ & $\begin{array}{l}€ 438 \pm € 71 \\
(315-554)\end{array}$ & $\begin{array}{l}€ 3006 \pm € 4500 \\
(34-26,147)\end{array}$ & $\begin{array}{l}€ 166 \pm € 140 \\
(32-554)\end{array}$ & $<0.0001$ \\
\hline & $\begin{array}{l}€ 1755 \pm € 2110 \\
(66-9927)\end{array}$ & & $\begin{array}{l}€ 9812 \pm € 6932 \\
(1755-26,626)\end{array}$ & & $\begin{array}{l}€ 3173 \pm € 4609 \\
(66-26,626)\end{array}$ & & $<0.0001$ \\
\hline
\end{tabular}




\section{ED visits}

During a bout, 25 (23.1\%) of 108 patients entered the ED because of $\mathrm{CH}$ attack (Table 2). Higher proportion of $\mathrm{CCH}$ patients visited the ED compared to $\mathrm{ECH}$ patients $(57.9 \%$ vs. $15.7 \% ; p<0.0001)$. The average number of ED visits per patient was higher for $\mathrm{CCH}(0.7 \pm 0.7$, range $0-2)$ than $\mathrm{ECH}(0.2 \pm 0.6$; range: $0-3 ; \mathrm{p}<0.0001)$.

The mean annual cost for the NHS relating to ED visits was $€ 71 \pm € 145$ (range: $€ 0-723$ ) per patient and the cost was higher for $\mathrm{CCH}(€ 165 \pm € 162)$ than $\mathrm{ECH}$ $(€ 51 \pm € 133 ; \mathrm{p}<0.0001)$ (Table 3).

\section{Medications consumption}

The allocation of intake of attack-aborting treatment and drugs is shown in Table 2. Regarding acute medications, $\mathrm{CCH}$ patients used significantly more sumatriptan $6 \mathrm{mg}$ and oxygen than EEC patients $(p=0.030$ and $p=$ 0.038 , respectively), while the use of zolmitriptan $5 \mathrm{mg}$ did not differ between the two groups. Higher proportion of $\mathrm{CCH}$ patients used more than one medication to treat the headache $(p=0.007)$. Regarding preventive medications, $\mathrm{CCH}$ patients used significantly more topiramate than ECH patients $(p=0.048)$, while the use of verapamil did not differ between the two groups. Higher proportion of $\mathrm{CCH}$ patients used a combination of two drugs as prevention $(p=0.001)$. Similarly, the use of transitional treatments, both oral corticosteroids and steroid suboccipital injections, was significantly higher for $\mathrm{CCH}$ than $\mathrm{ECH}$ patients $(p=0.002$ and $p<0.0001$, respectively). $\mathrm{CCH}$ patients also used more melatonin than ECH patients $(\mathrm{p}<0.0001)$.

The mean cost of acute medications for $\mathrm{CH}$ bout was $€ 2606 \pm € 4236$ (range: $€ 14-25,024$ ) per patient and was significantly higher for $\mathrm{CCH}(€ 8314 \pm € 6822)$ than $\mathrm{ECH}$ $(€ 1387 \pm € 1938 ; p<0.0001)$ (Table 3$)$. The mean cost of preventive medications for $\mathrm{CH}$ bout was $€ 102 \pm € 138$ (range: $€ 0-537)$ per patient and was significantly higher for $\mathrm{CCH}(€ 357 \pm € 74)$ than ECH $(€ 48 \pm € 70$; $\mathrm{p}<0.0001)$. The mean cost of transitional treatments for $\mathrm{CH}$ bout was $€ 20 \pm € 34$ (range: $€ 0-92$ ) per patient and was significantly higher for $\mathrm{CCH}(€ 66 \pm € 35)$ than $\mathrm{ECH}(€ 10 \pm € 24$; $p<0.0001$ ).

\section{Impact on work}

The mean number of days off work within the bout due to $\mathrm{CH}$ was nearly 7 days. Statistically the number of absence days due to headache was significantly larger among $\mathrm{CCH}$ patients $(15.2 \pm 11.8)$ than $\mathrm{ECH}$ patients $(5.6 \pm 7.9 ; p<.0001)$ (Table 4). On the contrary, the proportion of days off work respect to the bout duration was higher for $\mathrm{ECH}$ patients than $\mathrm{CCH}$ patients $(10.3 \%$ vs. $4.2 \%$, respectively; $p<.0001$ ), due to the longer duration of $\mathrm{CCH}$ bout. Overall, $\mathrm{CH}$ was responsible of nearly 16 days of work with reduced capacity. The impact of $\mathrm{CCH}$ was higher than that of $\mathrm{ECH}(46.3 \pm 72.2$ vs. $10.8 \pm 14.0$ days, respectively), but the difference was not significant. The reduction of productive capacity at work is shown in Fig. 1. The reports of work changes due to $\mathrm{CH}$ are shown in Fig. 2.

The mean cost of absences from work for $\mathrm{CH}$ bout was $€ 434 \pm € 952$ (range: $€ 0-5603$ ) per patient and was higher for $\mathrm{CCH}(€ 879 \pm € 1694)$ then ECH $(€ 339 \pm € 680)$, but the difference was not significant (Table 4). The mean cost attributed to days with reduced productive capacity for $\mathrm{CH}$ bout was $€ 792 \pm € 3541$ (range: $€ 0-29$, 501) per patient and was higher for $\mathrm{CCH}(€ 2659 \pm$ $€ 7818)$ then ECH (€393 $\pm € 1352)$, but the difference was not significant.

\section{Direct costs}

The mean direct costs of a $\mathrm{CH}$ bout were $€ 3173 \pm € 4609$ (range: €66-26,626) per patient and was covered for the

Table 4 Impact on work and indirect costs

\begin{tabular}{|c|c|c|c|c|}
\hline Diagnosis & $\begin{array}{c}\mathrm{ECH} \\
(n=77)\end{array}$ & $\begin{array}{c}\mathrm{CCH} \\
(n=12)\end{array}$ & $\begin{array}{l}\text { Total } \\
(n=89)\end{array}$ & $p$-value \\
\hline Days off work (or study), $n$. & $\begin{array}{c}5.6 \pm 7.9 \\
(1-45)\end{array}$ & $\begin{array}{l}15.2 \pm 11.8 \\
(5-45)\end{array}$ & $\begin{array}{c}6.9 \pm 9.1 \\
(1-45)\end{array}$ & $<0.0001$ \\
\hline Days off work (or study) / bout duration, \% & $\begin{array}{c}10.3 \pm 6.4 \\
(2-31)\end{array}$ & $\begin{array}{c}4.2 \pm 3.2 \\
(1-12)\end{array}$ & $\begin{array}{c}9.5 \pm 6.4 \\
(1-31)\end{array}$ & 0.000 \\
\hline Days with reduced productive capacity, $n$. & $\begin{array}{c}10.8 \pm 14.0 \\
(0-70)\end{array}$ & $\begin{array}{c}46.3 \pm 72.2 \\
(0-220)\end{array}$ & $\begin{array}{l}15.6 \pm 31.3 \\
(0-220)\end{array}$ & N.S. \\
\hline Days with reduced productive capacity / bout duration, $\%$ & $\begin{array}{c}18.1 \pm 16.3 \\
(0-52)\end{array}$ & $\begin{array}{c}12.7 \pm 19.8 \\
(0-60)\end{array}$ & $\begin{array}{c}17.4 \pm 16.8 \\
(0-60)\end{array}$ & N.S. \\
\hline Days off work (per bout) & $\begin{array}{c}€ 339 \pm € 680 \\
(0-3678)\end{array}$ & $\begin{array}{c}€ 879 \pm € 1694 \\
(0-5603)\end{array}$ & $\begin{array}{c}€ 434 \pm € 952 \\
(0-5603)\end{array}$ & N.S. \\
\hline Days with reduced productive capacity (per bout) & $\begin{array}{c}€ 393 \pm € 1352 \\
(0-11,648)\end{array}$ & $\begin{array}{c}€ 2659 \pm € 7818 \\
(0-29,501)\end{array}$ & $\begin{array}{c}€ 792 \pm € 3541 \\
(0-29,501)\end{array}$ & N.S. \\
\hline Total (per bout) & $\begin{array}{c}€ 732 \pm € 1.928 \\
(0-15,326)\end{array}$ & $\begin{array}{c}€ 3.538 \pm € 9420 \\
(0-34,865)\end{array}$ & $\begin{array}{c}€ 1226 \pm € 4374 \\
(0-34,865)\end{array}$ & N.S. \\
\hline
\end{tabular}




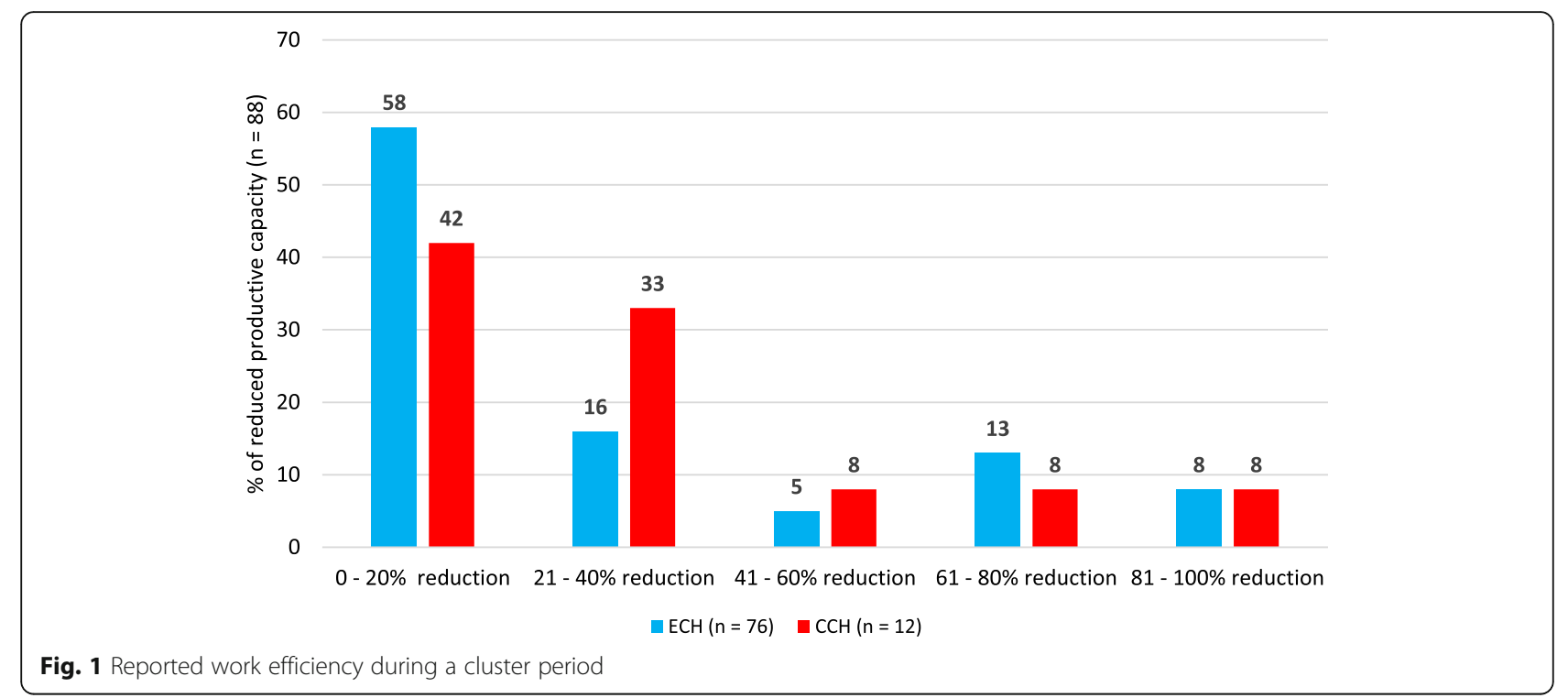

94.8\% (€3006) by the NHS (Table 3). The main item of expenditure was represented by treatments that accounted for $86 \%$ (€2728), followed by diagnostic tests for 6\% (€204), specialist visits for 5\% (€169) and ED visits for 3\% (€71) (Fig. 3). The mean direct costs of a $\mathrm{CH}$ bout were significantly higher for $\mathrm{CCH}(€ 9812 \pm$ $€ 6932)$ than ECH $(€ 1755 \pm € 2110 ; p<0.0001)$. There were small differences between the impact of the different expenditure items between $\mathrm{CCH}$ and $\mathrm{ECH}: 89 \%$ vs. $82 \%$ for treatments, $5 \%$ vs. $8 \%$ for diagnostic tests, $4 \%$ vs. $7 \%$ for specialist visits, and $2 \%$ vs. $3 \%$ for ED visits, respectively.

\section{Indirect costs}

The mean indirect costs for a $\mathrm{CH}$ bout were $€ 1226 \pm$ $€ 4374(€ 0-34,865)$ per patient and were higher for $\mathrm{CCH}$
$(€ 3.538 \pm € 9420)$ than $\mathrm{ECH}(€ 732 \pm € 1928)$, but the difference was not significant (Table 4). Days with reduced production capacity impacted for the 64.6\% (€792) of the total indirect costs.

\section{Analysis of total costs}

The mean total costs (direct + indirect) for a $\mathrm{CH}$ bout were $€ 4398 \pm € 7724(66-51,281)$ per patient and the direct costs accounted for $72.1 \%$ (€3173) (Fig. 4). The total cost of $\mathrm{CCH}(€ 13,350 \pm € 13,991$; range $2157-51,281)$ was 5.4 times higher than ECH $(€ 2487 \pm € 3394$; range $66-20$, 697; $p<0.001)$ and the difference in the total average costs of a $\mathrm{CH}$ bout between $\mathrm{CCH}$ and $\mathrm{ECH}$ was $€ 10,863$. The impact of direct costs on total expenditure was higher for $\mathrm{CCH}$ than $\mathrm{ECH}$ (73.5\% vs. $70.6 \%)$, but the difference was not significant.

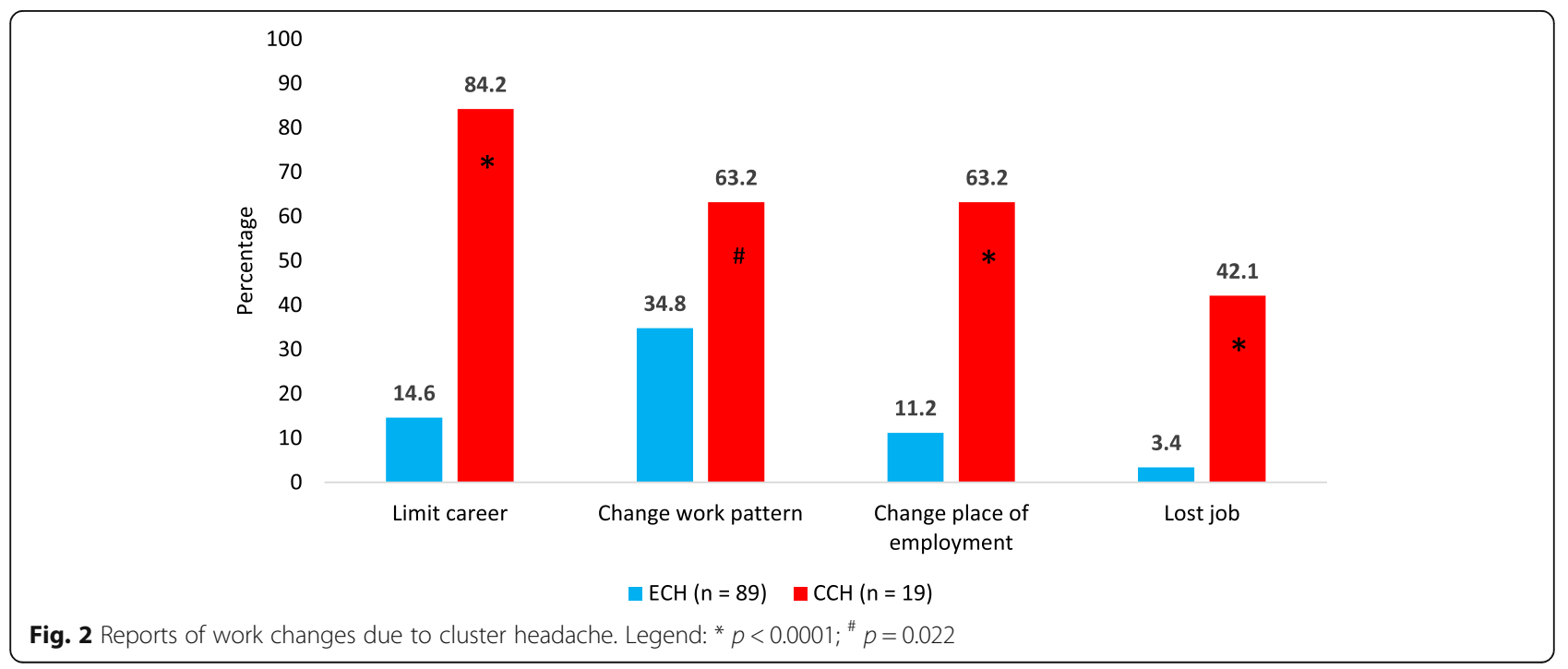




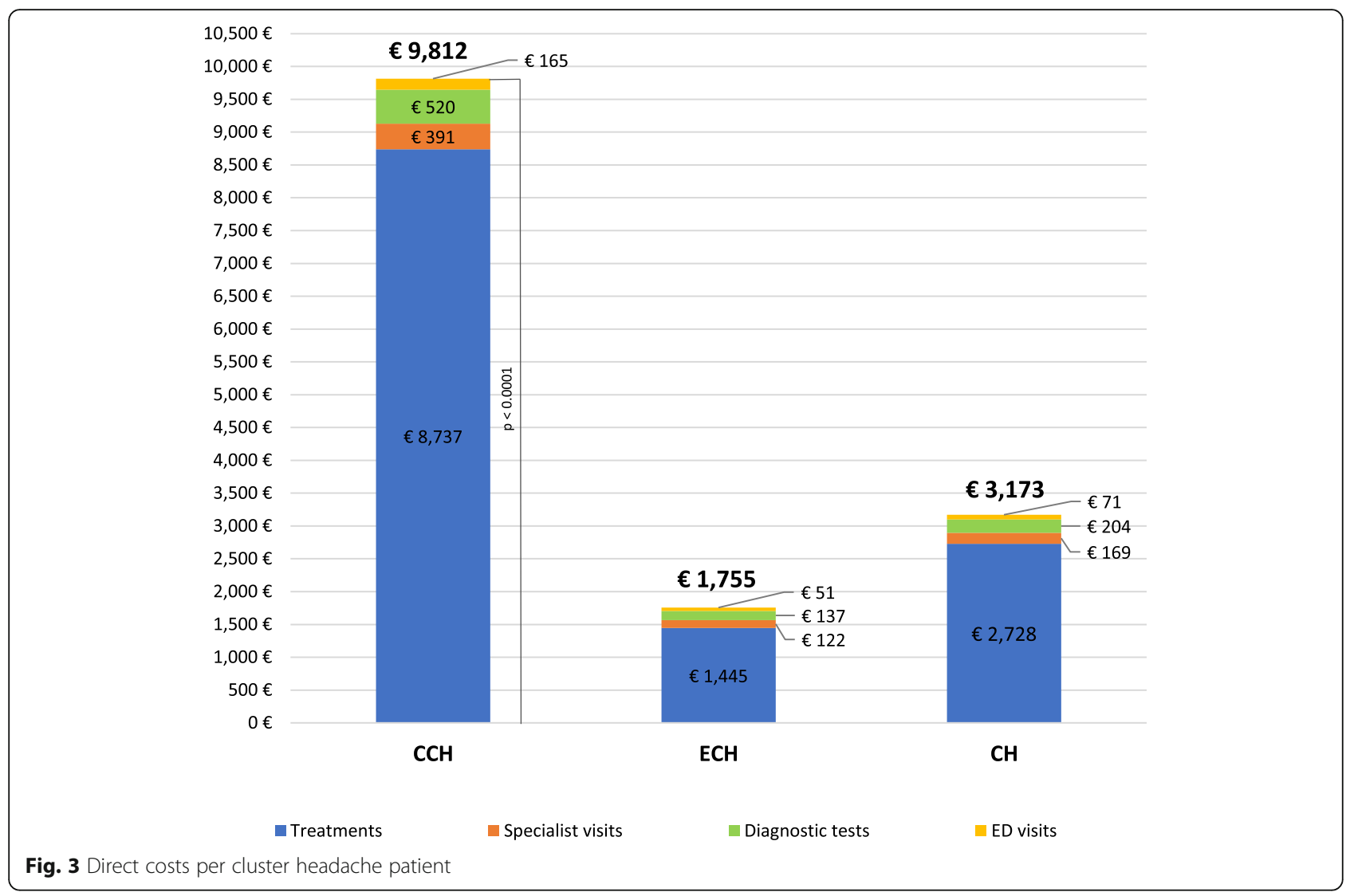

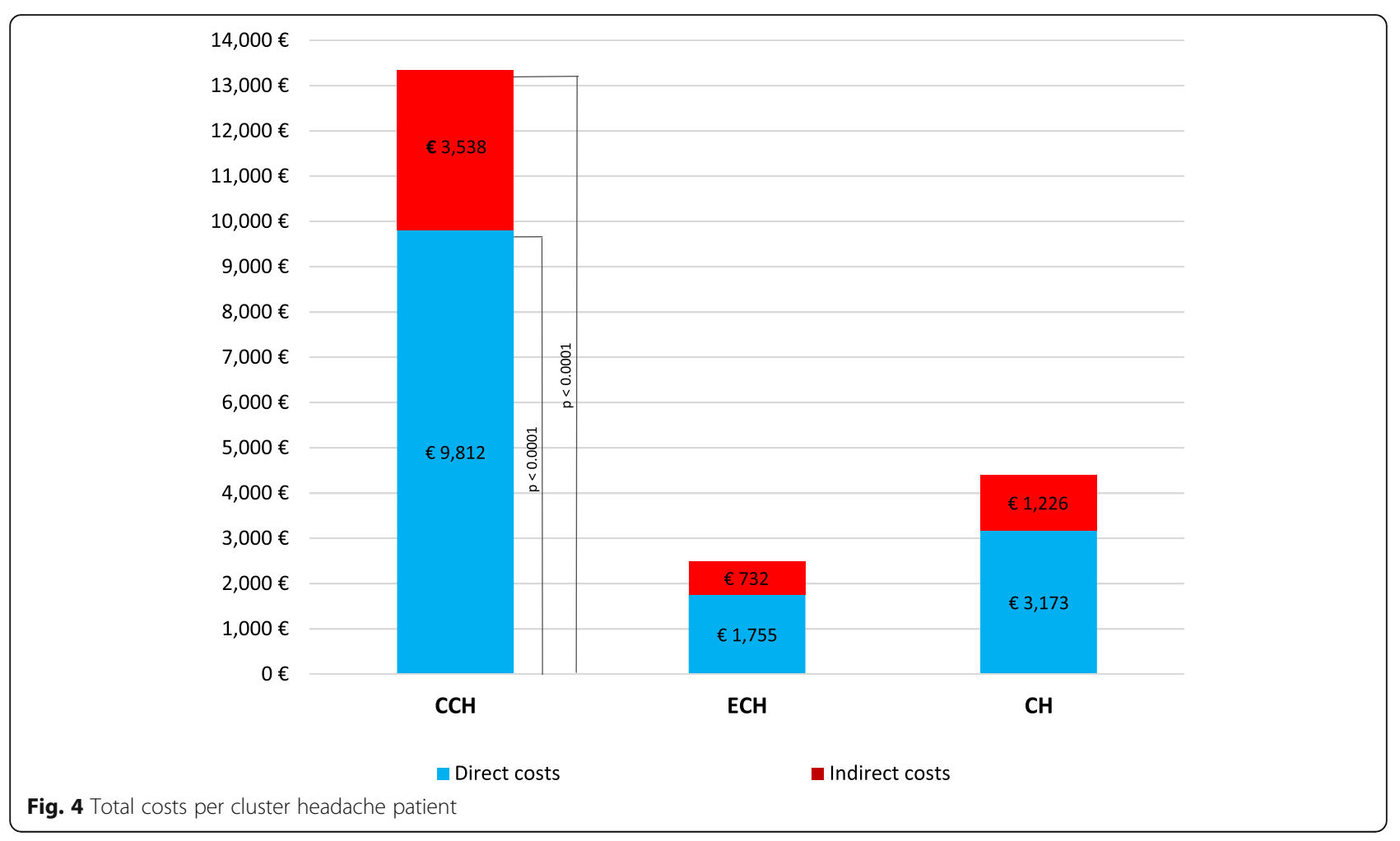




\section{Discussion}

Our study provides a detailed quantification of the mean direct and indirect costs associated with $\mathrm{ECH}$ and $\mathrm{CCH}$ (assessed with the ICHD-3 [1]) in a large population of patients attending an Italian tertiary level headache centre. Direct costs accounted for nearly three fourth of the total costs and $94.8 \%$ (€3006) was funded by the NHS while patients had an annual personal expenditure of $€ 167$ as a contribution for specialist visits, diagnostic tests, and medications. The total cost of $\mathrm{CCH}$ was 5.4 times higher than that of $\mathrm{ECH}$. The cost charged to the NHS was $€ 9374$ for $\mathrm{CCH}$ and $€ 1647$ for $\mathrm{ECH}$, while the cost for the patient was $€ 438$ for $\mathrm{CCH}$ and $€ 109$ for $\mathrm{ECH}$. The costs for any item of expense were higher for $\mathrm{CCH}$ than for $\mathrm{ECH}$. In fact, compared to $\mathrm{ECH}$ patients, $\mathrm{CCH}$ patients made 3-times more specialist visits and ED visits and 4-times more ECG and brain MRI. Overall, these data indicate that $\mathrm{CCH}$ patients have an increased need for follow-up due to the higher severity of the condition and the higher dose of preventive medications.

Only one other European study has recently assessed the cost of $\mathrm{CH}$ in our same setting of a headache centre. In 2010, Gaul et al. [8] retrospectively assessed the direct and indirect costs of $\mathrm{CH}$ diagnosed according to the second edition of the ICHD [15] in a sample of 179 patients (72 $\mathrm{CCH}, 107 \mathrm{CCH}$ ) attending a German headache centre. Unfortunately, important differences in the methodology and in the voices of expenditure considered between their and our study may limit a proper comparison of the results. The authors assessed the cost of a 6-month period while we prospectively evaluated the costs related to the duration of a $\mathrm{CH}$ bout. Moreover, Gaul et al. included the costs related to some drugs (e.g. lithium, gabapentin, valproate), specialist visits (e.g. pain specialist, osteopath, neurosurgeon) and procedures (e.g. physiotherapy, massage and manual therapy, acupuncture, occipital nerve stimulation) that we did not use in our patients [8]. In their study, hospitalization for headache treatment $(€ 24,086)$, rehabilitation $(€ 18,556)$ and the costs of surgery and hospitalization for occipital nerve stimulation $(€ 40,578)$ had an important impact on costs estimates. They estimated the total costs of a 6-month period in $€ 10,985$ per patient with $\mathrm{CCH}$ and $€ 2583$ per patient with $\mathrm{ECH}$.

As regard to indirect costs, in our study they represented $27.9 \%$ of the total cost of $\mathrm{CH}$ bout and, as expected, they were higher for $\mathrm{CCH}$ than $\mathrm{ECH}$ (€3.538 vs. $€ 732$ ), although not significantly. Days with reduced production capacity impacted for $64.6 \%$ of total indirect costs. $\mathrm{CCH}$ patients made significantly more absences from work than ECH patients $(15.2 \pm 11.8$ vs. $5.6 \pm 7.9)$ and, although the cost of days off work was higher for $\mathrm{CCH}$ then $\mathrm{ECH}(€ 879$ vs. $€ 339)$, the difference was not significant. A previous analysis conducted by Jensen et al. on $85 \mathrm{CH}$ patients $(20 \%$ with $\mathrm{CCH})$ in a Danish headache centre showed an important impact on work [9]. In detail, $39 \%$ of patients felt that $\mathrm{CH}$ had limited their career, $27 \%$ had changed their work pattern, $15 \%$ had changed their place of employment and 16\% had lost a job due to the disease. In our study, we investigated the same aspects and found similar results (27\%, $40 \%, 20 \%$ and $10 \%$, respectively). In addition, we also analyzed the impact of the two forms of $\mathrm{CH}$ separately, showing a significantly higher burden in association with $\mathrm{CCH}$. In detail, the ratio of the percentages of $\mathrm{CCH}$ and $\mathrm{ECH}$ patients for limitation of their career was $5.7: 1$, for the change of work pattern was 1.8:1, for the change of place of employment was 5.6:1 and for job loss was 12.4: 1 . When asked to quantify their work efficiency, $58 \%$ of $\mathrm{ECH}$ patients and $42 \%$ of $\mathrm{CCH}$ patients felt no or very few restrictions in their work efficiency, either because they had very effective and reliable treatment for the headaches or because most attacks occurred during night time and did not affect their daytime condition. Unexpectedly, we have not observed any differences in the severe reduction in production capacity between $\mathrm{CCH}$ and $\mathrm{ECH}$.

\section{Methodological considerations}

There are several important limitations that need to be considered when interpreting these results. Our study was conducted on a sample of patients attending a tertiary headache centre and our results may therefore not be representative of $\mathrm{CH}$ patients in the general population as specialist clinics usually see most disabled patients with a history of treatment failures and treatment attempts by general practitioners. However, most previous studies of $\mathrm{CH}$ have been conducted on patients from headache clinics. In addition, the proportion between $\mathrm{ECH}$ and $\mathrm{CCH}$ (82.4\% and $17.6 \%$, respectively) and duration of the disease (13 years) were similar to previous epidemiological series and our results can therefore be comparable to both studies conducted in the same setting of a headache clinic [9] and most other populationbased studies $[16,17]$. The higher proportion of $\mathrm{CCH}$ patients in a tertiary headache centre compared than in the general population may result in more people refractory to conventional treatment. In our population, 15 of the $19 \mathrm{CCH}$ patients had refractory $\mathrm{CCH}$ according to the definition proposed by EHF [5]. Refractory patients use more healthcare resources and more acute treatments, and because of their higher and permanent disability compared to other patients, they show a greater work impairment leading to increased indirect costs. Unfortunately, the detailed analysis of this subgroup of patients has not been made. However, we believe that demographic and clinical $\mathrm{CH}$ characteristics of our patients' sample are those typical of a cohort of $\mathrm{CH}$ 
and, therefore, our population may be comparable to other clinical populations $[8,17]$.

With regard to the cost analysis, we have calculated only the direct and indirect costs closely related to $\mathrm{CH}$, but not the cost of conditions that are comorbid or secondary to $\mathrm{CH}$ or to its treatment, which can have a strong economic impact on the management of $\mathrm{CH}$. Taking those aspects into account, the cost of headache would be even higher. Our economic analyses have been designed to capture only the costs associated with a $\mathrm{CH}$ bout, from the day of the onset until the end of the active period with suspension of the pharmacological treatment and final follow-up at our headache centre. Consequently, we have not assessed the cost of the referring general practitioners, which in Italy is entirely covered by the NHS. Likewise, we have not assessed the costs of physicians, resident doctors and nurses (fully covered by the NHS) or the costs of medications (e.g. lithium) and procedures (e.g. surgery, transcutaneous nerve stimulators and acupuncture) which for various reasons are not routinely used in our clinic. A further limitation of our economic analysis is that we have not calculated the indirect costs due to the impact of $\mathrm{CH}$ on family life.

An advantage of this study is the high validity of the headache diagnosis, which was assessed by a headache expert. In contrast, studies in which patients were identified by administrative claims as opposed to medical records showed the potential for misclassification of migraine or chronic migraine as $\mathrm{CH}$ [10]. In addition, administrative claims data may be subject to data encoding limitations and data entry error and, in some countries, may be limited only to individuals with employee health insurance or supplemental insurance, so that they cannot be representative of all $\mathrm{CH}$ patients.

To our knowledge, this study is the first to establish the diagnosis according to the most recent and currently used third version of the ICHD criteria, which presents important differences form the second edition used in previous studies [15].

However, the main advantage of this study is the adoption of a prospective design that has never before been used before for "cost of illness" studies for $\mathrm{CH}$. In fact, recall bias is usually a major problem in retrospective clinical studies, even for highly debilitating diseases such as $\mathrm{CH}$, for which one might expect most patients to be able to remember their attacks accurately. However, recall specific data on drug consumption and days off work or with reduced productivity is usually more unreliable. Instead, we have carried out a detailed analysis by collecting information on every single attack during the $\mathrm{CH}$ period and calculating in detail the changes in drug use. This method provides more reliable data on health resource utilization than other studies that have calculated the number of attacks by multiplying the frequency of attacks per day by the duration of the $\mathrm{CH}$ bout [8].

\section{Conclusions}

Our results provide a valuable estimate of the direct and indirect costs of patients with $\mathrm{ECH}$ and $\mathrm{CCH}$ in the specific setting of a tertiary level headache centre and confirm the high economic impact of $\mathrm{CH}$ on both the NHS and patients. $\mathrm{CCH}$ Patients had more visits, diagnostic tests and drug use than patients with $\mathrm{ECH}$, which led to a total cost of 5.4 times that of ECH.

Cost of illness studies become obsolete due to changing healthcare systems and new treatments become available. Governments and decision-makers should strongly support these investigations to reveal the true economic and social impact of this devastating pain disease, particularly when it is chronic.

\section{Abbreviations}

$\mathrm{CH}$ : Cluster headache; $\mathrm{CCH}$ : chronic cluster headache; DRG: Diagnosis related Group; ECG: Electrocardiogram; EHF: European Headache Federation; EMR: Electronic medical records; ECH: Episodic cluster headache;

ED: Emergency department; GON: Great occipital nerve; ICHD: International Classification of Headache Disorders; MRI: Magnetic resonance imaging; NHS: National Health System

\section{Acknowledgements}

Not applicable.

\section{Authors' contributions}

AN: study design, data acquisition, data analysis and interpretation, drafting the manuscript. PS: study design, statistical analysis, data analysis and interpretation. VS: data acquisition, data analysis and interpretation. PM: study design, conception of the study and revising the manuscript critically. FSM: study design, conception of the study and revising the manuscript critically. The authors read and approved the final manuscript.

\section{Funding}

This paper was not funded.

\section{Availability of data and materials}

Dataset available from the corresponding author on reasonable request.

Ethics approval and consent to participate

Study protocol was submitted to the Ethics Committee.

\section{Consent for publication}

Not applicable.

\section{Competing interests}

A. Negro received travel grants, consulting fees and speaking fees from Allergan, Eli Lilly, Novartis, and TEVA.

P. Martelletti received travel grants, consulting fees and speaking fees from Allergan, Amgen, Eli Lilly, Novartis, and TEVA.

The authors have no other relevant affiliations or financial involvement with any organization or entity with a financial interest in or conflict with the subject matter or materials discussed in this manuscript apart from those disclosed.

\section{Author details}

'Department of Clinical and Molecular Medicine, Sapienza University, Rome, Italy. ${ }^{2}$ Regional Referral Headache Centre, Sant'Andrea Hospital, Rome, Italy. ${ }^{3}$ Economic Evaluation \& HTA (CEIS- EEHTA), Faculty of Economics, University of Rome Tor Vergata, Rome, Italy. ${ }^{4}$ Department of Statistical Sciences, 
Sapienza University of Rome, Rome, Italy. ${ }^{5}$ Institute for Leadership \&

Management in Health, Kingston University London, London, UK.

Received: 14 March 2020 Accepted: 15 April 2020

Published online: 04 May 2020

\section{References}

1. Headache classification committee of the International Headache Society (IHS) (2018) The international classification of headache disorders, 3rd edition. Cephalalgia 38(1):1-211

2. Fischera M, Marziniak M, Gralow I, Evers S (2008) The incidence and prevalence of cluster headache: a meta-analysis of population-based studies. Cephalalgia. 28(6):614-618

3. Bahra A, May A, Goadsby PJ (2002) Cluster headache: a prospective clinical study with diagnostic implications. Neurology. 58(3):354-361

4. Manzoni GC, Micieli G, Granella F, Tassorelli C, Zanferrari C, Cavallini A (1991) Cluster headache--course over ten years in 189 patients. Cephalalgia. 11(4): 169-174

5. Mitsikostas DD, Edvinsson L, Jensen RH, Katsarava Z, Lampl C, Negro A, Osipova V, Paemeleire K, Siva A, Valade D, Martelletti P (2014) Refractory chronic cluster headache: a consensus statement on clinical definition from the European headache federation. J Headache Pain 15:79

6. Hoffmann J, May A (2018) Diagnosis, pathophysiology, and management of cluster headache. Lancet Neurol 17(1):75-83

7. Rozen TD, Fishman RS (2012) Cluster headache in the United States of America: demographics, clinical characteristics, triggers, suicidality, and personal burden. Headache. 52(1):99-113

8. Gaul C, Finken J, Biermann J, Mostardt S, Diener HC, Müller O, Wasem J, Neumann A (2011) Treatment costs and indirect costs of cluster headache: a health economics analysis. Cephalalgia. 31(16):1664-1672

9. Jensen RM, Lyngberg A, Jensen RH (2007) Burden of cluster headache. Cephalalgia. 27(6):535-541

10. Ford JH, Nero D, Kim G, Chu BC, Fowler R, Ahl J, Martinez JM (2018) Societal burden of cluster headache in the United States: a descriptive economic analysis. J Med Econ 21(1):107-111

11. Regional Rate Nomenclator. Available at: http://www.regione.lazio.it/binary/ rl_sistemi_informativi_sanitari/tbl_contenuti/Nomenclatore_2015_DCA_6 04_2015.xls. Accessed 11 Dec 2019

12. Pronto Soccorso e sistema 118 - Proposta metodologica per la valutazione dei costi dell'emergenza, Progetto Mattoni - Ministero della Salute. Available at: http://www.mattoni.salute.gov.it/mattoni/documenti/11_ Valutazione_costi_dell_emergenza.pdf. Accessed 11 Dec 2019.

13. Federfarma. Available at: https://www.federfarma.it/Farmaci-e-farmacie/ Cerca-un-farmaco.aspx. Accessed 11 Dec 2019.

14. Mennini FS, Gitto L, Martelletti P (2008) Improving care through health economics analyses: cost of illness and headache. J Headache Pain 9(4): 199-206

15. Headache Classification Subcommittee of the International Headache Society (2004) The International Classification of Headache Disorders. 2nd edn. Cephalalgia 24(Suppl 1):9-160

16. Tonon C, Guttmann S, Volpini M, Naccarato S, Cortelli P, D'Alessandro R (2002) Prevalence and incidence of cluster headache in the Republic of San Marino. Neurology. 58(9):1407-1409

17. Ekbom K, Svensson DA, Träff H, Waldenlind E (2002) Age at onset and sex ratio in cluster headache: observations over three decades. Cephalalgia. 22(2):94-100

\section{Publisher's Note}

Springer Nature remains neutral with regard to jurisdictional claims in published maps and institutional affiliations.

Ready to submit your research? Choose BMC and benefit from:

- fast, convenient online submission

- thorough peer review by experienced researchers in your field

- rapid publication on acceptance

- support for research data, including large and complex data types

- gold Open Access which fosters wider collaboration and increased citations

- maximum visibility for your research: over $100 \mathrm{M}$ website views per year

At $\mathrm{BMC}$, research is always in progress.

Learn more biomedcentral.com/submissions 